Article

\title{
Investigation of Sinkhole Formation with Human Influence: A Case Study from Wink Sink in Winkler County, Texas
}

\author{
Shannon English ${ }^{1}$, Joonghyeok Heo ${ }^{1, * \mathbb{D}}$ and Jaewoong Won ${ }^{2}$ \\ 1 Department of Geosciences, University of Texas - Permian Basin, Odessa, TX 79762, USA \\ 2 Department of Real Estate, Graduate School of Tourism, Kyung Hee University, Seoul 02447, Korea \\ * Correspondence: heo_j@utpb.edu
}

Received: 1 March 2020; Accepted: 20 April 2020; Published: 26 April 2020

check for updates

\begin{abstract}
The formation of sinkholes in Winkler County, Texas is concerning due to the amount of oil and gas infrastructure and the potential for catastrophic losses. Evidences of new and potential sinkholes have been documented, and determining the cause of these sinkholes is paramount to mitigate the devastating consequences thereof. Studies have shown that the Wink sinkholes result from both natural and anthropogenic influences. Data depicting land-cover changes, alterations in the hydrologic systems, climate changes, and oil and gas activity were analyzed in an effort to better understand the link between these processes and sinkhole formation. Results indicate that the combination of these processes lead to the current state. Land cover changes were highest in shrub versus grasses, undeveloped to developed and croplands. Rises in temperature and a decrease in precipitation indicate a shift towards a more arid climate. Changes to the hydraulic system are a direct result of these land cover changes while the groundwater quality depicts an environment prone to dissolution. Historical oil and gas activities have created pathways of meteoric water infiltration to the underlying limestone and evaporite formation. The combination of these processes create an environment that accelerates sinkhole formations. Understanding these processes allows for the development and implementation of better land practices, better groundwater protections, and the need for monitoring and maintaining aging oil and gas infrastructure.
\end{abstract}

Keywords: Wink sink; sinkhole; oil and gas developments; anthropogenic activities; environmental causes; Texas

\section{Introduction}

Sinkholes occur where overburden on the surface collapses into karst or a void within the subsurface. The formation of sinkholes is usually unforeseen and can create catastrophic losses of life and property, hence the term "hidden threat" is designed to describe this phenomenon [1,2]. Numerous sinkholes have been documented throughout the world. Many have natural causes such as climate events; examples of the such sinkholes include the May 30, 2010 sinkhole formation in Guatemala City, Guatemala, presumed to be caused by tropical storm Agatha, in which the sinkhole developed under a three-story building and killed one man, while another notable example is a sinkhole in Deltona, Florida, where it is believed that the occurrence of three hurricanes over the area lead to the December 13, 2004 formation of the sinkhole, which appeared under a four-lane highway. Others have anthropogenic sources including human activities. Picher, Oklahoma is home to numerous sinkholes due to mining activities prominent in the area, and thus is unsuitable for human habitation. On February 23, 1998, an underground pipe rupture caused the development of a sinkhole by Interstate 15 [3].

Sinkholes are most likely to form in karst terrain and are often found in areas of artesian flow [4]; all 50 states have such terrain and $18 \%$ of this terrain is underlain with soluble lithologies [5], making the 
prediction of sinkhole formation almost impossible. The study area contains many of the features; most notable of such features are the presence of limestone and dolomite formations, which are notorious for karst development, as well as underlying evaporates, which are highly soluble and prone to dissolution with the introduction of waters undersaturated with respect to the dominant salts such as sodium chloride $(\mathrm{NaCl})$ and potassium chloride $(\mathrm{KCl})$, among others. Naturally occurring and anthropogenic pathways of water infiltration dominate the study area, making the development of sinkholes an issue of concern.

The development of Wink Sink \#1 in 1980 illustrates this point. On 3 June 1980, the first sinkhole appeared in Winkler County, Texas. Within $24 \mathrm{~h}$, the sinkhole had grown to a width of $110 \mathrm{~m} \mathrm{[6]}$. Wink Sink \#1 was joined by Wink Sink \#2 on 21 May 2002, approximately $1500 \mathrm{~m}$ to the south of the original sinkhole [1]. Neither collapse was predicted or expected. Luckily, there was no loss of life during the formation of either sinkhole. However, it has been proposed that humans played a significant role in the formation of both sinkholes, specifically through oil and gas development. Concerns over additional sinkhole development, and ways to predict them, have become a primary research topic within this area.

Several studies have investigated at the impact of early oil and gas activities in the Hendrick Field, which surrounds the Wink sinkholes along with sinkhole formation mechanisms [1,6-11] in evaluating the dissolution of underlying salt and evaporite formations. They attributed the acceleration of the development of the sinkholes to human-made pathways for the introduction of fresh meteoric waters to the Castille and Salado. The development of the Hendrick field began in the 1920's and the procedures used during this time, such as a lack of intermediate casing, when coupled with the dissolution that had already occurred during previous geologic time, have exacerbated the naturally occurring dissolution of underlying evaporite formations leading to the subsequent formation of the Wink Sink. Sinkhole development increases in instances where the salt beds are overlain with other strata [12], as is the case within the study area. The dissolution of salt and other evaporites, suffusion, and fracturing $[11,13]$ of underlaying formations weakens overlying formations structurally. When the structure has been weakened past the point of supporting itself, it will collapse. This process continues until reaching the surface, forming the sinkhole.

Accounting for both the natural and anthropogenic sources of sinkhole formation is vital to understanding sinkhole formation and expansion. This research investigates environmental changes in conjunction with human activities with the goal of correlating the two in relation to the Wink Sink area. Historical changes in land use, precipitation, and temperature were analyzed to develop a comprehensive explanation behind the continual expansion of the existing Wink Sinks and currently developing sinkholes in the surrounding area. The purposes of this study are (1) to assess the land and climate changes in Winkler County, Texas; (2) to evaluate the groundwater qualities in the study area; and (3) to identify and investigate human influences in Wink Sink. This research contributes to an understanding of sinkhole formation and provides important information for sinkhole areas in making decision and development plans in the future.

\section{Study Area and Methods}

\subsection{Study Area}

The study area (Figure 1a) is located within the northeastern part of the Chihuahuan Desert in the Trans-Pecos region of West Texas in Winkler county, approximately $3.2 \mathrm{~km}$ north-northeast of the city of Wink. The climate is semi-arid with the temperature widely ranging from below freezing to over $40{ }^{\circ} \mathrm{C}$, low precipitation, and high rates of evaporation. Precipitation is the highest in spring and fall seasons [14-16]. Land cover is predominantly grasses, shrubs, and brush, followed by barren lands, then developed areas and crops. This area is also characterized by high volumes of oil and gas exploration, drilling, and production activities. The semi-transient population varies in conjunction with oil and gas operations. 


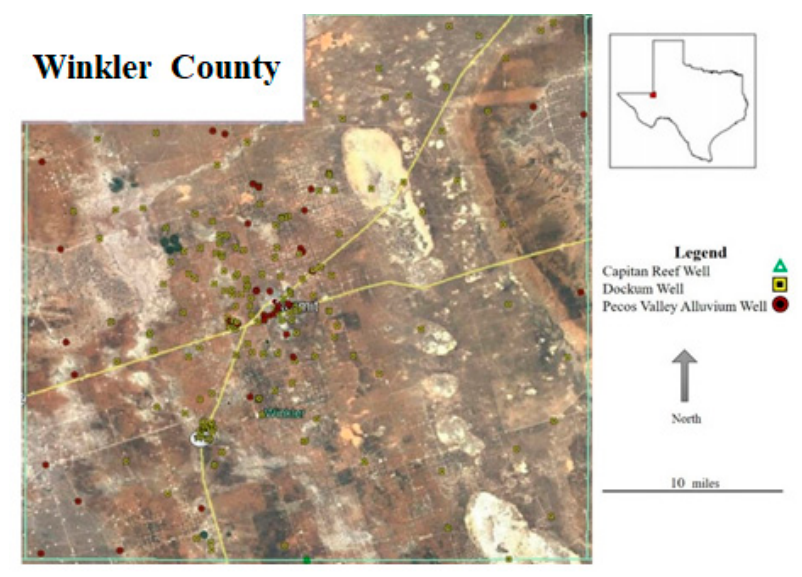

(a) Location map

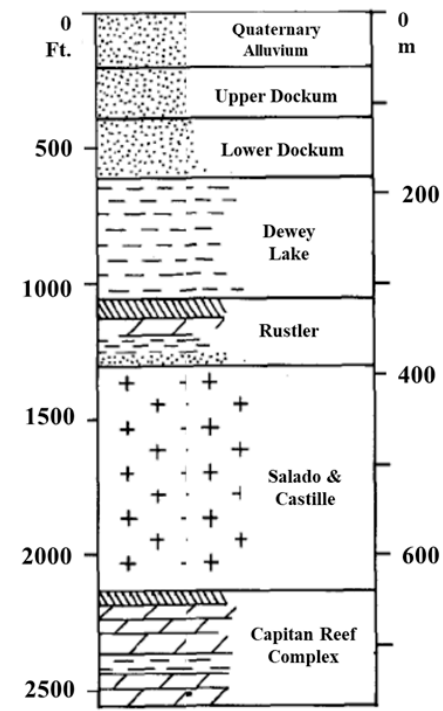

(b) Geologic profile

Figure 1. Maps of the study area showing the (a) general location and (b) geologic profile for Winker County, West Texas.

Geologically, the study area is situated on the western side of the Monument Draw trough, on the shelf margin between the Central Basin Platform and the Delaware Basin on the western side of Permian Basin. This region has a complex and varied geologic history; deposition began during the Paleozoic Era, in a stable, and shallow marine environment. Significate uplift and deformation occurred during Mississippian with the Ouchita orogeny. The Pennsylvanian and Permian periods consisted of subsidence and deposition in the Delaware Basin that correspond with uplift and erosion on the Central Basin Platform [17]. The Capitan Reef complex was deposited during the Guadalupian series, followed by the Ochoan deposits of the Castille and Salado evaporites, the Rustler formation [18], and finally the Dewey Lake Redbeds. Deposition of the Dockum group during the Triassic marks a basin wide continental depositional event. Marine transgression during the Cretaceous was followed by an uplift and erosion of the Cretaceous deposits during the Laramide orogeny [17]. Dissolution of the Salado and Castille evaporites throughout the Cenozoic resulted in the collapse of the overlying Rustler, Dewy Lake, and Dockum formations and subsequent in-filling of the Pecos Valley Alluvium. Figure $1 \mathrm{~b}$ illustrates a geologic structure in the study area. The two largest of these collapse features in the Delaware Basin are the Pecos Trough of central basin and Monument Draw Trough of eastern basin. The Monument Draw Trough runs north to south following the Capitan Reef Complex. According the Texas Water Development Board (TWDB), there is one major aquifer and two minor aquifers located in the study area: the Pecos Valley Aquifer (PVA) (major), the Dockum (minor), and the Capitan Reef Complex (minor) [16].

\subsection{Methods}

In order to better understand the link between anthropogenic and natural influences on sinkhole formation, changes in land cover and climate were analyzed. Data acquired to complete the historical assessment of land cover and land changes was obtained through Texas Natural Resource Information System (TNRIS), the U.S. Geological Survey (USGS), and the United States Department of Agriculture (USDA) Lab in Temple, TX. These datasets included layers that were added into ArcGIS to build maps spanning a 20-year period. The type of changes assessed were water, developed land, barren land, brush land, grass land, and crop land. Precipitation and temperature data between 1980 to 2015 were gathered from the National Oceanic and Atmospheric Administration (NOAA). Alterations within 
these data sets were analyzed and interpreted as indications of overall climate change within the study area.

Data for water quality were obtained from the Texas Water Development Board (TWDB). Data from every well with reported water quality parameters within Winkler County was gathered for the PVA, Dockum, and Capitan Reef aquifers. Comingled aquifer data was not used in an effort to detect any changes or patterns within the specific aquifer. A total of 218 wells met these qualifications. The data ranged from the 1940 's to the 2010's; data distribution consisted of 180 PVA wells, 37 Dockum wells, and 1 Capitan Reef well. However, data availability decreased from the 1970's through the 2010's. Due to the limitations and disparities within the data set, decadal averages were used. The parameters chosen were chloride, total dissolved solids (TDS), bicarbonate, and $\mathrm{pH}$. Chloride concentration was used as an indication of oil and gas activity influence. TDS, bicarbonate, and $\mathrm{pH}$ values help to determine if the environment was experiencing dissolution of evaporite and carbonate formations. The changes in the local groundwater system due to the alterations in land cover and climate were then assessed along with the influence of historical oil and gas development along with water quality. The correlation of these datasets indicates a highly nuanced interrelationship between each set of data and sinkhole formation.

\section{Results}

\subsection{Land-Cover Changes}

Data from TNRIS indicates significant alterations in land cover between 1992, as shown in Figure 2, and 2011, as shown in Figure 3. The most significant changes in land-cover are the decrease of grass and barren lands, and the increase in cropland and developed areas. These changes are summarized in Table 1 . These changes influence the local hydrology by altering the elements in the local hydraulic system, most importantly run-off, infiltration, and groundwater recharge. Land-cover changes can be traced to both anthropogenic sources, including oil and gas developments, and naturally occurring sources, such as climate change.

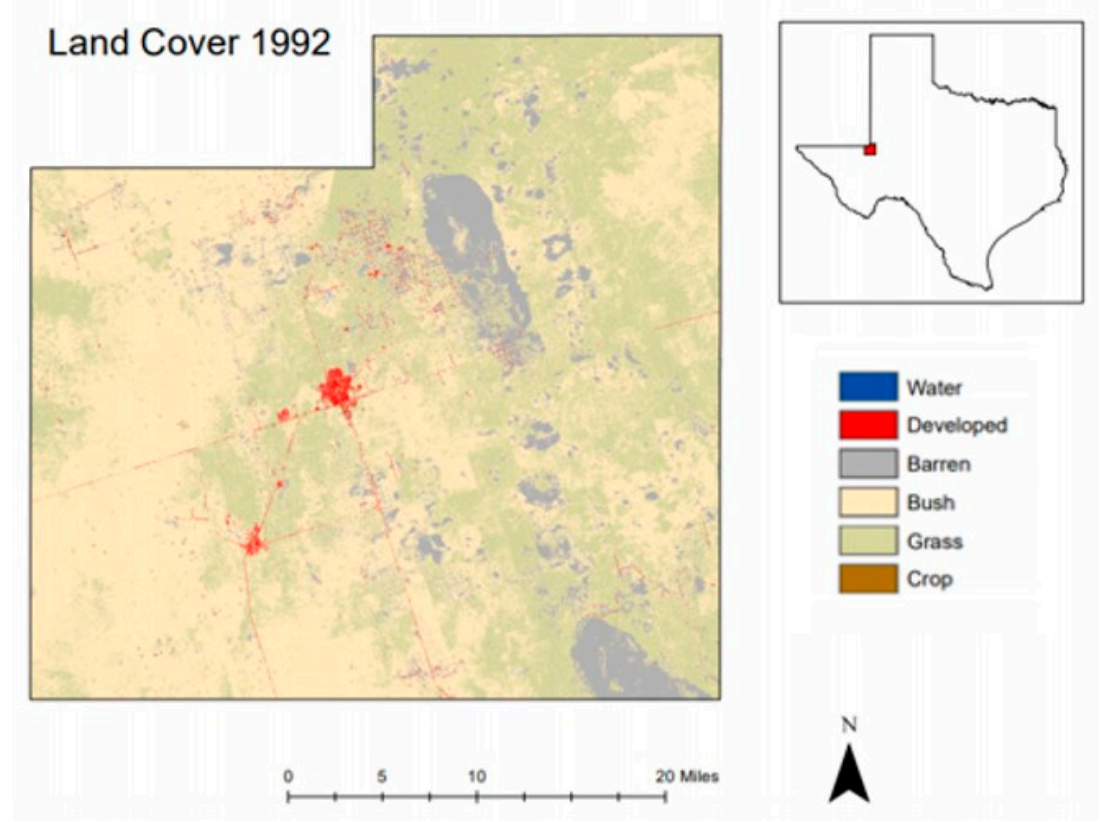

Figure 2. Land-cover map in 1992 for the study area. 
Land Cover 2011

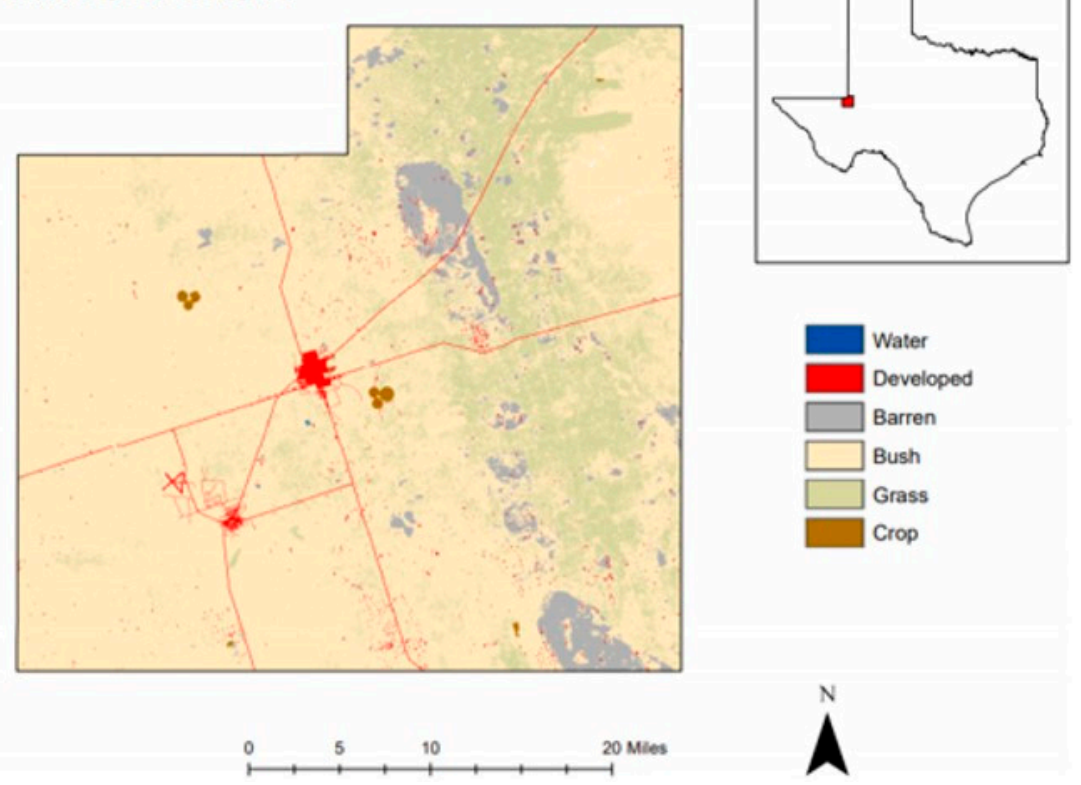

Figure 3. Land-cover map in 2011 for the study area.

Table 1. Summary of land-cover changes between 1992 and 2011.

\begin{tabular}{ccccccc}
\hline & \multicolumn{6}{c}{ Area of Land Cover Changes $\mathbf{( k m}^{\mathbf{2}} \mathbf{)}$} \\
\cline { 2 - 7 } & Developed & Barren & Brush/Shrub & Grass & Crop & Water \\
\hline 1992 & 145.3 & 2075.9 & $11,834.9$ & 7688.2 & 3.0 & 0.0 \\
2011 & 280.4 & 1064.1 & $16,357.3$ & 3994.4 & 40.5 & 1.1 \\
Percent Difference & $63 \%$ & $-64 \%$ & $32 \%$ & $-63 \%$ & $173 \%$ & $184 \%$ \\
\hline
\end{tabular}

Data from 1992-2011 depict a significant increase (approximately 63\%) in developed land area. Urbanization increases the amount of runoff due to impervious areas with a decrease in evaporation, transpiration, and infiltration within the developing areas [19]. The data also indicates an increase of cropland by approximately $173 \%$. Land uses of pasture and cropland resulted in an increase in soil compaction and soil densities, which in turn resulted in precipitation runoff of $54.5 \%$ [20]. This alteration greatly increased the amount of run-off, while significantly impacting the local groundwater systems.

\subsection{Climate Changes}

Annual total precipitation shows a decreasing slope of -0.4 from 1980 to 2015 . The average precipitation was $32.8 \mathrm{~cm}$ for the observation period. Average annual temperature increased from 18.1 to $18.9^{\circ} \mathrm{C}$ during the period of $1980-2015$. The average temperature was $18.7^{\circ} \mathrm{C}$ for the period of $1980-2015$. The results of anomaly show that the study area experiences a definite decrease in precipitation and high increase in temperature. Figure $4 \mathrm{a}$ is a linear regression of annual temperature data showing the average increase of annual temperatures through the past three decades, while Figure $4 \mathrm{~b}$ plots the anomalies of annual temperatures. Figure $4 \mathrm{c}$ depicts the decline in precipitation rates and Figure $4 \mathrm{~d}$ shows the anomalies within the precipitation data. This analysis confirms a shift to a more arid climate within the study area. 


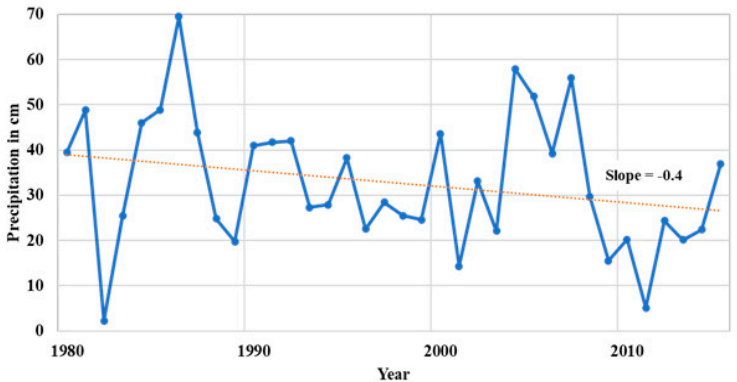

(a) Annual total precipitation

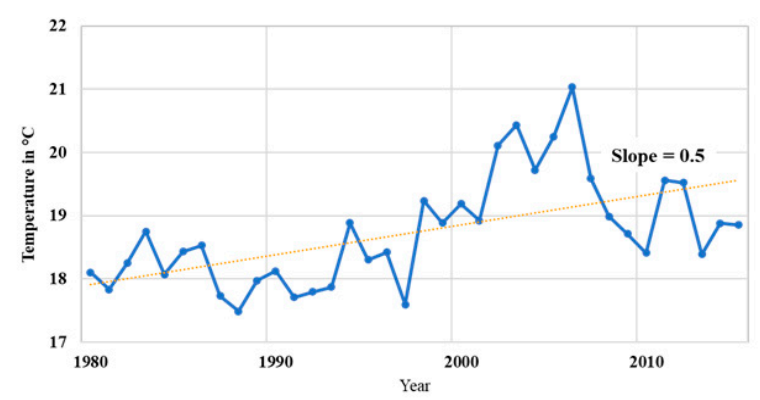

(c) Average annual temperature

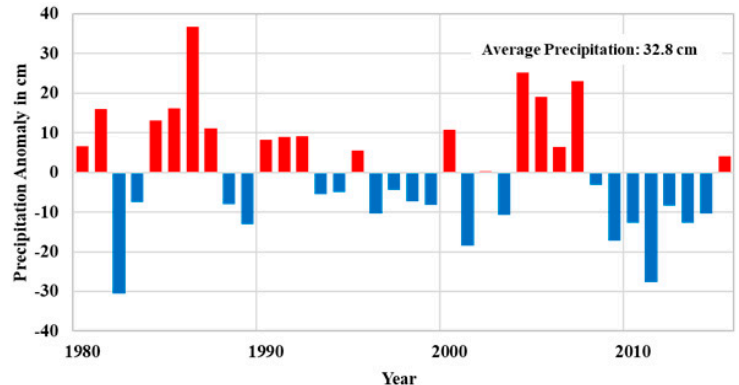

(b) Precipitation anomaly

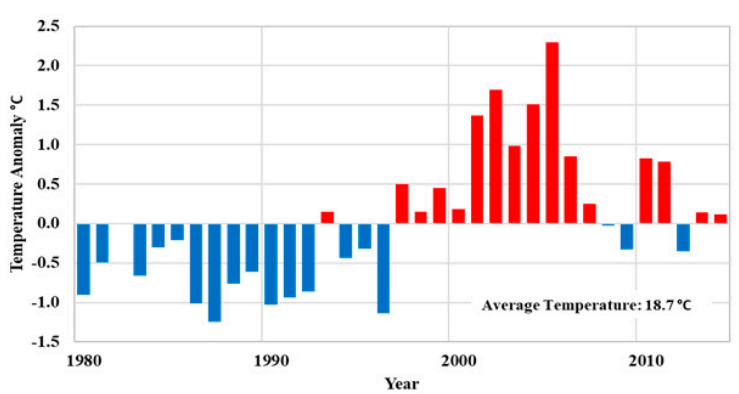

(d) Temperature anomaly

Figure 4. Climate change in Winkler County for (a) annual total precipitation, (b) precipitation anomalies, (c) average annual temperature, and (d) temperature anomalies from 1980 to 2015.

During times of prolonged drought, such as ones occurring currently within the study area, there is an increase in soil stresses. The stress on soils increases the ability of soils to transmit fresh waters to underlying strata. As the soils dry, they become less cohesive and increase in porosity, or conversely, harden and become denser. During periods of drought, ground fissures are formed by an increase in effective stress of overlying strata. These fissures are pathways of water infiltration into the evaporite layers, increasing the rate of dissolution [1].

\subsection{Groundwater Changes}

The PVA is an unconfined aquifer characterized by unconsolidated alluvial and eolian sediments consisting of interbedded sand, silt, clay, caliche, and gravels (Table 2). Average hydraulic conductivity was calculated to be $2.6 \mathrm{~m}$ per day with estimated transmissivity values of less than 1.0 to greater than $4267 \mathrm{~m}$ per day [17]. It is primarily used for agricultural purposes with some use in public water systems and industrial purposes. The PVA ranges in depth from less than a meter to $457 \mathrm{~m}$ in depth. Although highly variable, TDS values range from less than $1000 \mathrm{mg} / \mathrm{L}$ to over $3000 \mathrm{mg} / \mathrm{L}$ [21]. Average decadal TDS values from 1940 through 1970, shown in Figure 5a, ranged from a high of approximately $2363 \mathrm{mg} / \mathrm{L}$ in 1950 to a low of approximately $1368 \mathrm{mg} / \mathrm{L}$ in 1960, well above the freshwater standard of $1000 \mathrm{mg} / \mathrm{L}$ and the EPA Secondary Drinking Water Standards (SDWS) of $500 \mathrm{mg} / \mathrm{L}$ [22]. A rapid decrease in TDS concentration occurred in 1980, falling to $874 \mathrm{mg} / \mathrm{L}$. This decline continued through 2010, when concentration reached $448.2 \mathrm{mg} / \mathrm{L}$. 
Table 2. Aquifer properties in the study area.

\begin{tabular}{ccccccc}
\hline \multirow{2}{*}{$\begin{array}{c}\text { Aquifer } \\
\text { Name }\end{array}$} & Aquifer Type & \multicolumn{2}{c}{$\begin{array}{c}\text { Approximate } \\
\text { Thicknesses (ft) }\end{array}$} & $\begin{array}{c}\text { Average } \\
\mathbf{p H}\end{array}$ & Description \\
\cline { 3 - 4 } & & Top & Bottom & & \\
\hline $\begin{array}{c}\text { Pecos Valley } \\
\text { Alluvium }\end{array}$ & Alluvial & Unconfined & 0 & 1500 & 7.60 & $\begin{array}{c}\text { Aeolian and eolian sediments } \\
\text { consisting with beds of clay, silt, } \\
\text { sand, gravel, and caliche. }\end{array}$ \\
\hline Dockum & Sandstone & $\begin{array}{c}\text { Confined \& } \\
\text { Unconfined }\end{array}$ & 160 & 1300 & 7.59 & Fine grained sandstone. \\
\hline Capitan Reef & Limestone & Confined & 3000 & 4400 & 6.53 & Karsted limestone and dolomite. \\
\hline
\end{tabular}

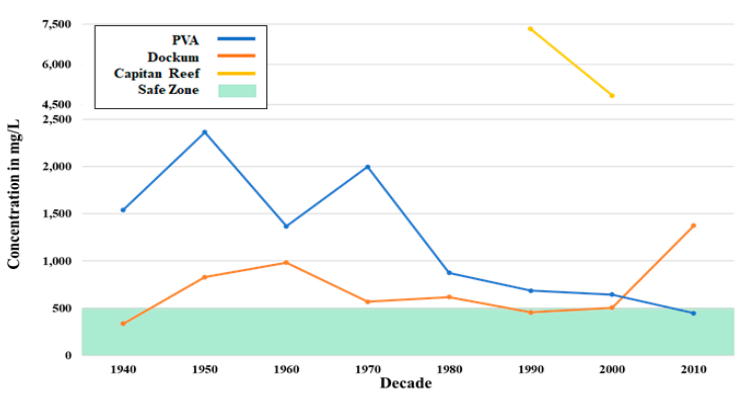

(a) TDS

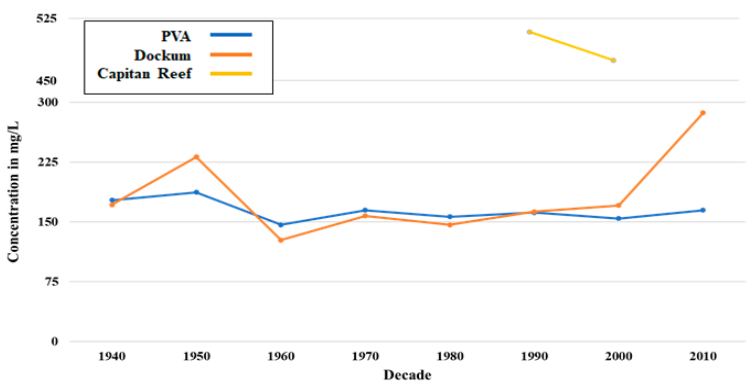

(c) Bicarbonate

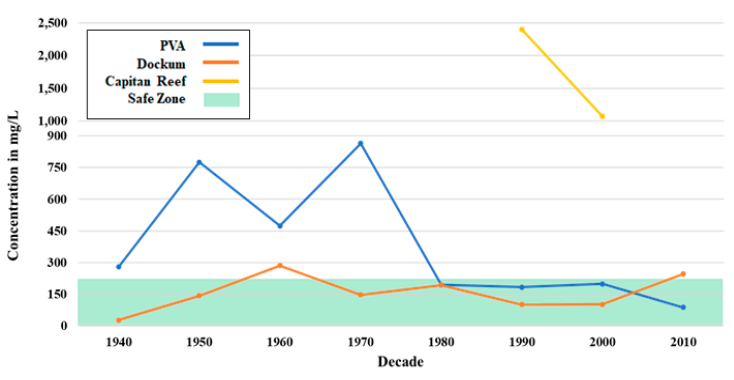

(b) Chloride

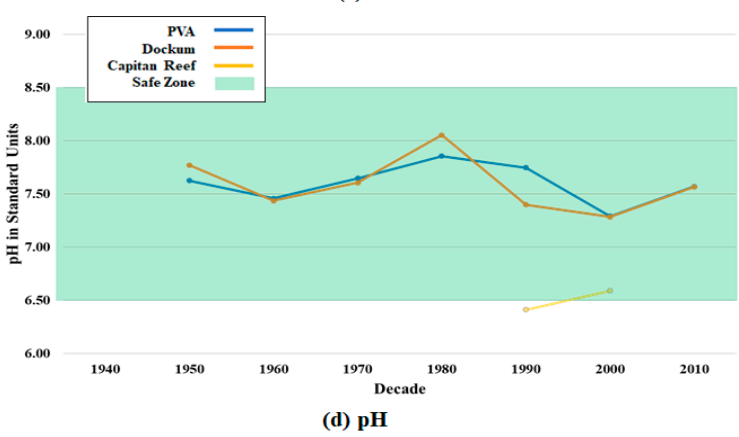

Figure 5. Aqueous geochemical data for the Pecos Valley Alluvium, Dockum, and Capitan Reef aquifers. Decadal averages are of (a) TDS (total dissolved solids), (b) chloride, (c) bicarbonate, and (d) pH.

The same pattern is observed in the chloride concentration. From 1940 through 1970, chloride values were elevated above the SDWS of $250 \mathrm{mg} / \mathrm{L}$ [22] with a peak in $1970 \mathrm{of} 864.4 \mathrm{mg} / \mathrm{L}$. From 1980 to 2000, chloride levels remained constant until a decrease in 2010, to $87.9 \mathrm{mg} / \mathrm{L}$ (Figure 5b). Throughout the eight decades of water quality data available, the PVA bicarbonate (Figure $5 \mathrm{c}$ ) and $\mathrm{pH}$ levels (Figure 5d) have remained fairly consistent. Bicarbonate concentrations ranged from a high of $187.1 \mathrm{mg} / \mathrm{L}$ in 1950 to a low of $146.4 \mathrm{mg} / \mathrm{L}$ in 1960 . The $\mathrm{pH}$ values peaked a slightly basic value of 7.85 in 1980 and a more neutral low of 7.29 in 2000, followed by an increase in 2010, to 7.57.

The Dockum is a sandstone aquifer and the basal member of the Dockum formation, with the upper layers being predominantly siltstone and claystone. The Pecos Valley Alluvium Formation rests uncomfortably on the Dockum. Where the upper Dockum members are in place, the aquifer is confined. In areas where these confining members have been eroded away, the PVA and Dockum are hydraulically connected. Water quality parameters from these comingled areas were not analyzed in this study. The depth of the Dockum ranges from $39.3 \mathrm{~m}$ to $396 \mathrm{~m}$ [23]. It produces fresh to saline waters and is used for agricultural and domestic purposes along with oil and gas supply [16] within the study area.

The Dockum aquifer regularly demonstrated higher water quality than the PVA until 2010. TDS concentrations began at a low of $336.2 \mathrm{mg} / \mathrm{L}$ in 1940 and did not exceed the freshwater line until 2010, approximately $1374 \mathrm{mg} / \mathrm{L}$ (Figure 5a). Chloride values were typically low, breaching the 
SDWS only in 1960 at $285.6 \mathrm{mg} / \mathrm{L}$. In 2010, chloride concentration rose to $246.5 \mathrm{mg} / \mathrm{L}$ (Figure 5b). Bicarbonate concentrations showed some fluctuation between 1950 and 1960, peaking at $231.4 \mathrm{mg} / \mathrm{L}$ and declining to $127.3 \mathrm{mg} / \mathrm{L}$, respectively, before remaining consistent through 2000, then rising to $286.8 \mathrm{mg} / \mathrm{L}$ in 2010 (Figure 5c). However, pH values were most basic in 1980 at 8.05 and the most neutral in 2000 with a value of 7.28 . The 2010 average $\mathrm{pH}$ value showed an increase the same as the PVA, rising to 7.57 (Figure $5 \mathrm{~d}$ ).

The elevated TDS and chloride values within the PVA and Dockum are interpreted to be anthropogenic; stemming from historical oil and gas practices such as the used of unlined produced water pits to store produced water. These waters contain high concentrations of chloride, TDS [24], and hydrocarbons, allowing lower quality water to infiltrate into the PVA and some areas of the Dockum [17]. Once this practice changed, through regulations of the Texas Administration Code (TAC) $\$ 16.1 .3$ [25] in the 1970's, water quality increased. The dramatic shift from high TDS and chloride to low within the two upper aquifers destabilized the geochemical environment leading to higher rates of dissolution. The first Wink Sink collapsed in 1980, which progressively changed the overall geochemical data in groundwater (Figure 5). Wink Sink \#2 collapsed in 2002. Water quality before the collapse had continued to improve, thus continuing to introduce fresh water to the underlying formations. While water quality within the PVA is still trending towards fresher waters, the Dockum has undergone a shift toward more brackish waters. This could be an indication of the deeper formational brines upwelling and mixing into the Dockum as the underlying formations are dissolved.

The Capitan Reef aquifer is a fractured and karst limestone aquifer. Depth to aquifer ranges from $914 \mathrm{~m}$ to over $1219 \mathrm{~m}$. Despite the use of numerous wells within the study area for oil and gas, water quality data was limited to one well over two decades. The Capitan exhibited the poorest water quality within the study area. The poor water quality is a factor of formational age, residence time [26], depositional environment, depth, and oil and gas development [27-29]. The Capitan can be considered as one of the sources of the deep basin brines within the study area. Figure 5a shows TDS values two to three times higher than the PVA peak in 1950, ranging from $7327 \mathrm{mg} / \mathrm{L}$ in 1990 to $4845 \mathrm{mg} / \mathrm{L}$ in 2000. Figure $5 \mathrm{~b}$ shows that chloride concentrations were $2402 \mathrm{mg} / \mathrm{L}$ in 1990 and $1070 \mathrm{mg} / \mathrm{L}$ in 2000. Bicarbonate values (Figure 5c) were also nearly double in PVA and Dockum concentrations, yet $\mathrm{pH}$ values (Figure 5d) indicate that the environment was more acidic. In 1990, pH was 6.41 and 6.59 in 2000. Due to the substantially higher quality water of the PVA and Dockum aquifers along with the presence of the semi-confining and confining lithology overlying the Capitan Reef complex, it has been inferred that there is little to no naturally occurring hydraulic connectivity between aquifers within the study area and any subsequent mixing or upwelling is a direct result of anthropogenic influences [30].

\section{Discussion}

\subsection{Land-Cover Changes}

The changes in land-cover can be summarized as the increase in cropland and developed areas, and the decrease of grass and barren lands. Within the study area, developed land is not limited to an increase in urbanization. Oil and gas activities increase the amount of impervious land cover due to the construction of lease roads, drilling pads, and other infrastructures with little to no restoration of natural ground cover at the completion of these activities. These changes influence the local hydrology by altering the elements in the local hydraulic system, most importantly run-off, infiltration, and groundwater recharge. Thus, the land-cover changes can be traced to both anthropogenic sources, including developed land, oil, and gas developments, and naturally occurring sources, such as climate change.

The loss of grasslands and increase of shrubs are attributed to the relationship between root systems, soil type, and water availability. While grasses develop deep root systems that are capable of deep soil moisture uptake, shrubs are capable of an even deeper penetration, developing root systems into partially weathered bedrock [20]. Additionally, a higher content of calcium carbonate within the 
soil may inhibit microbial activity, effectively limiting the amount of macronutrients available within the soils needed for grasses to thrive [31]. The overwhelming majority of soil within the study area is dominated by calcium carbonate-based lithology due to the deposition and erosion of vast limestone deposits throughout geologic history, the most recent during the Cretaceous period. Within the areas of shrub-based vegetation, eolian sediments (including minerals and organic matter) are trapped and settled within the zones of shrubs. This creates an environment that allows the shrub vegetation to thrive and overwhelm even more grassland. Grassland are also more sensitive to climate conditions such as drought, while the shrub cover remains and thrives [31]. This change in vegetation leads to more surface run-off and less infiltration of precipitation.

\subsection{Climate Changes}

Analysis of precipitation and temperature data from 1980 to 2015 revealed an increase in annual average temperature with a decrease in annual precipitation indicating a shift to a more arid climate and drought conditions. The shift to more arid and drought-prone conditions alters both vegetation and soil conditions. During drought conditions, vegetation dies, thereby reducing groundcover, soil moisture uptake and evapotranspiration. The scarcity of precipitation decreases water supplies and increases the drying of surfaces soils [32].

As climate change progresses, the volume of fissures and increase in infiltration rates will also progress. An increase in severe drought conditions in an already arid environment will accelerate this process. Formation of new sinkholes can be expected, especially in the areas that this process has already begun, such as the current study area. Evidence of this occurring to the east and north Wink Sink \#2 has been found showing a rate of subsidence of up to about $13 \mathrm{~cm}$ per year, possibly indicating a development and location of a new sinkhole. In conjunction with this finding, additional subsidence has been occurring around Wink Sink \#1, indicating that a future growth of a sinkhole may be imminent [1].

\subsection{Groundwater Changes}

The increase in runoff due to land cover changes combined with climate alterations and its subsequent effects on soils poses a unique issue within the study area. With the anthropogenic alterations in ground cover limiting the area of soils capable of infiltration, the potential for the development of localized, new catchment basins and runoff pathways increases [2]. The concentrated influx of groundwater in these specific locations may potentially alter groundwater flow patterns and recharge zones. The increased burden of water in overlying strata coupled with increased withdrawal and subsequent lowering of hydraulic head in underlying aquifers, such as the Rustler, increases site-specific inter-aquifer flow and plays an active role in dissolution [2]. When overlying aquifers of higher hydraulic head were connected to underlying aquifers of lower head, water will flow into the lower-head aquifer through permeable strata or through improperly sealed boreholes [6].

Recent increases in production of groundwater from the Rustler Formation in the Delaware Basin may be increasing this exchange. Typical production rates from Rustler wells are in the range of 300 gallons per minute (gpm) to over $700 \mathrm{gpm}$. There have been few studies on the impact this withdrawal has had on the Rustler and its hydraulically connected counterparts [33,34]. The Rustler, along with the Salado and Castille, has undergone several instances of deformation resulting in faulting, jointing, and collapse throughout the Delaware Basin, all of which allow for the flow of water through the formation [35]. This allows for the introduction of meteoric waters into underlying evaporites and an increase in dissolution.

The alterations in land cover by creating new catchment zones and limiting recharge areas accelerates the process. Dissolution has been ongoing well into the tertiary [2] and has continued to today. When water falls through the atmosphere and percolates through the over burden, $\mathrm{CO}_{2}$ is dissolved, forming weak carbonic acid $\left(\mathrm{H}_{2} \mathrm{CO}_{3}\right)$. As the $\mathrm{H}_{2} \mathrm{CO}_{3}$ infiltrates the underlying carbonate and evaporite formation, the formation dissolves. The amount of dissolution can be estimated through 
TDS concentrations. As the amount of carbonate and evaporite dissolved in the water increases, TDS concentrations also increase. This dissolution occurs especially fast around the areas of focused infiltration [13] and dissolution rates within these evaporite layers can be up to three times faster than that are seen in limestone lithology [12], especially with the introduction of water undersaturated with respect to the dominate salt within the evaporite. As more waters percolate down and through the underlying Salado and Castille, the development of sinkholes could greatly increase in both the rate and quantity of the development.

\subsection{Oil and Gas Development}

Significant soil pollution occurs from oil and gas development due to spills of crude oil and brines [36,37]. Spills of crude oil from well sites and pipelines are also major sources of soil pollution in oil-producing areas. Such spills can move down through the soil and contaminate groundwater, or up through the soil and be released into the air. Brines have high salinity levels and can also contain toxic trace elements and naturally occurring radioactive materials. Soil pollution at oil and gas production wells is caused primarily by the intentional, accidental, and incidental discharge of drilling fluids, crude petroleum, and refined petroleum products [37].

Oil and gas development changes the land-cover map by removing initial land-cover types, creating large concrete building surfaces, and developing new transportation networks [38]. The oil and gas sites often intrude into forest lands, agricultural lands, and grass lands. People working at oil and gas sites often move and aggregate into a nearby city or town. Furthermore, deforestation caused by oil production or converting grassland into developed land has deep effects on the environment, such as loss of habitats for animal and plant species, and could be a critical factor driving climate change locally. This disruption in a region can lead to changes in local soil moisture and extreme temperatures, which can harm plants and even humans.

As the surrounding infrastructure of the Hendrick Oil Field ages, concerns over what are now seen as improper practices and their unforeseen consequences rise. Wells were drilled vertically, a mere $201 \mathrm{~m}$ apart from other wells. Numerous boreholes were deviated, and as was the case in Hendrick Well 10-A (the location of Wink Sink \#1), explosives were used to allow for re-drilling of a straighter hole. Explosives were also used to increase production within oil-bearing zones [7], as a precursor to modern fracking techniques. The fracturing of rocks with explosives resulted in uncontrolled fractures being formed throughout the zone, unlike today's highly engineered and scientific methods. These fractures increased permeability for oil production, but also created the necessary conduit to allow the unsaturated waters to have continuous access to the dissolution-prone, underlying formations [2].

Records of plugging and abandoning wells are sparse, and regulations were drastically different than today. Improperly plugged wells, again such as Hendrick Well 10-A [5], have created new pathways of water migration through the overburden, and there is insufficient data to determine where these wells are located or how many there are. As a pipe ages, it corrodes and the well itself can become a direct pathway to the delicate underlying strata. Wells that did not utilize secondary and tertiary casing and cementing are also potential pathways. If the well bore is lacking in cement throughout the entire borehole above the targeted zone, meteoric waters will use these pathways to flow. If cement was placed in the borehole behind the pipe, incomplete cementing jobs would still allow for water to flow behind the cement. Unbeknownst to the workers of the Hendrick Field, the actions taken then may have set in motion for the events that are culminating in the development of sinkholes today and for an unforeseeable time in the future.

\section{Conclusions}

The results of this study indicate sinkhole development in the Wink area of Winkler County, Texas is due to a combination of anthropogenic and naturally occurring circumstances. As the climate continues to change, the effects will be seen in the alterations of natural vegetation and soil behaviors. 
When this is coupled with anthropogenic alterations in land use and land cover, the development of sinkholes is accelerated. In order to protect the public and existing infrastructure, a more in-depth understanding of the relationship between the two is necessary. The results of this research have indicated that the historical and current practices of the oil and gas industry are one of the primary anthropogenic sources of sink hole formation within the study area. A more in-depth study on methods to contain, eliminate, or mitigate the effect of aging oil and gas infrastructure coupled with better land cover and land use practices that include an awareness of runoff and drainage issues, management of local water table conditions, and utilization of current technologies during urbanization within the study area could potentially allow for better prediction and containment of sink holes.

While the prediction will heavily depend on advanced technologies and consistent monitoring of known and potential sinkhole formation sites, re-stabilization efforts of the surrounding land cover and identification of failing infrastructure will be two key areas to consider to prevent the development of more sinkholes. The reintroduction of native grasslands, monitoring of both overlying and underlying aquifers, and proper drainage management are some of the available methods that this study suggests the possible stabilization of surrounding areas. Conducting site specific experiments with these goals would be the next step according to the findings within this study. While it may be beyond the scope of these experiments to alter the climate, altering the stewardship of the land is not beyond current scientific capabilities.

Author Contributions: S.E. collected detailed information on the sinkhole, calculated the environmental and groundwater changes, and analyzed the results with conclusions. J.H. designed the structure, developed the arguments, and contributed for the overall paper. J.W. contributed data curation, validation, review and editing. All authors have read and agreed to the published version of the manuscript.

Funding: This work was supported by a Rising STAR (Science and Technology Acquisition and Retention) Program from the University of Texas System.

Conflicts of Interest: The authors declare no conflict of interest.

\section{References}

1. Kim, J.W.; Lu, Z.; Degrandpre, K. Ongoing Deformation of Sinkholes in Wink, Texas, Observed by Time-Series Sentinel-1A SAR Interferometry (Preliminary Results). Remote Sens. 2016, 8, 313. [CrossRef]

2. Lambert, S.J. Dissolution of Evaporites in and Around the Delaware Basin, Southeastern New Mexico and West Texas. Sandia Rep. 1983, 82, 461.

3. Hansen, L.7 Terrifiying Sinkhole Disasters. Available online: https:/theweek.com/articles/466766/7-terrifyingsinkhole-disasters (accessed on 10 October 2019).

4. Land, L. Geophysical Records of Anthropogenic Sinkhole Formation in the Delaware Basin Region, Southeast New Mexico and West Texas, USA. Carbonates Evaporties 2013, 28, 183-190. [CrossRef]

5. Weary, D.J.; Doctor, D.H. Karst in the United States: A Digital Map Compilation and Database; U.S. Geological Survey: Reston, VA, USA, 2014. [CrossRef]

6. Johnson, K.S. Sinkholes and Subsidence over Salt at Wink, Texas. Universtiy Okla. 2005, 323, 321-325.

7. Johnson, K.S. Development of the Wink Sink in West Texas, U.S.A., Due to Salt Dissolution and Collapse. Environ. Geol. Water Sci. 1989, 14, 81-92. [CrossRef]

8. Johnson, K.S.; Collins, E.W.; Seni, S.J. Sinkholes and Land Subsidence Owing to Salt Dissolution near Wink, Texas and Other Sites in Western Texas and New Mexico. Oklahoma Geol. Surv. Circ. 2003, 109, 183-196.

9. Shalev, E.; Lyakhovsky, V.; Yechieli, Y. Salt Dissolution and Sinkhole Formation along the Dead Sea Shore. J. Geophys. Res. Solid Earth 2006, 111. [CrossRef]

10. Johnson, K.S. Dissolution of Permian Salado Salt during Salado Time in the Wink Area, Winkler County, Texas. In Proceedings of the Forty-Fourth Annual Field Conference Guidebook, New Mexico Geological Society, New Mexico, NM, USA, 15-16 February 1993; pp. 211-218.

11. Baryakh, A.; Fedoseev, A.K. Sinkhole formation mechanism. J. Min. Sci. 2011, 47, 404-412. [CrossRef]

12. Frumkin, A.; Ezersky, M.; Al-Zoubi, A.; Akkawi, E.; Abueladas, A.R. The Dead Sea Sinkhole Hazard: Geophysical Assessment of Salt Dissolution and Collapse. Geomorphology 2011, 134, 102-117. [CrossRef] 
13. Tihansky, A.B. Sinkholes, West-Central Florida. A Link between Surface Water and Ground Water. L. Subsid. United States 1999, 1182, 121-140.

14. Ashworth, J.B. Evaluation of Ground-Water Resources in Parts of Loving, Pecos, Reeves, Ward, and Winkler Counties, Texas; TWDB (Texas Water Development Board) Report 317: Austin, TX, USA, 1990; 51p.

15. Menne, M.J.; Durre, I.; Vose, R.S.; Gleason, B.E.; Houston, T.G. An Overview of the Global Historical Climatology Network-Daily Database. J. Atmos. Ocean. Technol. 2012, 29, 897-910. [CrossRef]

16. Menne, M.J.; Durre, I.; Korzeniewski, B.; McNeal, S.; Thomas, K.; Yin, X.; Anthony, S.; Ray, R.; Vose, R.S.; Gleason, B.W.; et al. Global Historical Climatology Network-Daily (GHCN-Daily), Version 3 Daily Summaries. Available online: https://data.nodc.noaa.gov/cgi-bin/iso?id=gov.noaa.ncdc:C00861\# (accessed on 13 October 2019). [CrossRef]

17. Meyer, J.E.; Wise, M.R.; Kalaswad, S. Pecos Valley Aquifer, West Texas: Structure and Brackish Groundwater; TWDB (Texas Water Development Board) Report 382: Austin, TX, USA, 2012; p. 95.

18. Standen, A.; Finch, S.; Williams, R.; Lee-Brand, B.; Kirby, P. Capitan Reef Complex Structure and Stratigraphy; Texas Water Development Board: Austin, TX, USA, 2009; pp. 1-52.

19. Dow, C.L.; DeWalle, D.R. Trends in Evaporation and Bowen Ratio on Urbanizing Watersheds in Eastern United States. Water Resour. Res. 2000, 36, 1835-1843. [CrossRef]

20. Heo, J.; Yu, J.; Giardino, J.; Cho, H. Water resources response to climate and land-cover changes in a semi-arid watershed, New Mexico, USA. Terr. Atmos. Ocean. Sci. 2015, 26, 463-474. [CrossRef]

21. George, P.G.; Mace, R.E.; Petrossain, R. Aquifers of Texas; TWDB (Texas Water Development Board) Report: Austin, TX, USA, 2011; p. 182.

22. Safe Drinking Water Act. Available online: epa.gov/sdwa (accessed on 19 October 2019).

23. TWDB Water Data Interactive. Available online: https://www3.twdb.texas.gov/apps/WaterDataInteractive/ GroundWaterDataViewer (accessed on 1 October 2019).

24. Rouhi, H.; Kalantari, N. Hydrogeochemistry and Groundwater Mixing Close to an Oil Field: An Example from Asmari Karstic Aquifer, Khuzestan, Iran. Water Sci. Technol. Water Supply 2018, 18, 357-370. [CrossRef]

25. Texas Admininistrative Code.

26. Guo, J.; Zhou, X.; Wang, L.; Zhang, Y.; Shen, X.; Zhou, H.; Ye, S.; Fang, B. Hydrogeochemical Characteristics and Sources of Salinity of the Springs near Wenquanzhen in the Eastern Sichuan Basin, China. Hydrogeol. J. 2018, 26, 1137-1151. [CrossRef]

27. Saller, A.H. Differential Compaction and Basinward Tilting of the Prograding Capitan Reef Complex, Permian, West Texas and Southeast New Mexico, USA. Sediment. Geol. 1996, 101, 21-30. [CrossRef]

28. Melim, L.A.; Scholle, P.A. Dolomitization of the Capitan Formation Forereef Facies (Permian, West Texas and New Mexico): Seepage Reflux Revisited. Sedimentology 2002, 49, 1207-1227. [CrossRef]

29. Fantle, M.S.; Higgins, J. The Effects of Diagenesis and Dolomitization on Ca and Mg Isotopes in Marine Platform Carbonates: Implications for the Geochemical Cycles of Ca and Mg. Geochim. Cosmochim. Acta 2014, 142, 458-481. [CrossRef]

30. Rozell, D.J.; Reaven, S.J. Water Pollution Risk Associated with Natural Gas Extraction from the Marcellus Shale. Risk Anal. 2012, 32, 1382-1393. [CrossRef]

31. Stavi, I.; Rachmilevitch, S.; Yizhaq, H. Geodiversity Effects on Soil Quality and Geo-Ecosystem Functioning in Drylands. Catena 2019, 176, 372-380. [CrossRef]

32. Naumann, G.; Alfieri, L.; Wyser, K.; Mentaschi, L.; Betts, R.A.; Carrao, H.; Spinoni, J.; Vogt, J.; Feyen, L. Global Changes in Drought Conditions Under Different Levels of Warming. Geophys. Res. Lett. 2018, 45, 3285-3296. [CrossRef]

33. Boghici, R. Hydrogeological Investigations at Diamond Y Springs and Surraounding Area, Pecos County, Texas; The University of Texas at Austin: Austin, TX, USA, 1997.

34. Robertson, W.M.; Allen, J.T.; Wolaver, B.D.; Sharp, J.M. 2019, 570, 850-862. [CrossRef]

35. Rodriguez, J.; Heo, J.; Park, J.; Lee, S.; Miranda, K. Inorganic pollutants in the water of Midland and Odessa, Permian Basin, west Texas. Air, Soil and Water Research 2019, 12, 1-7. [CrossRef]

36. Meng, Q. The impact of fracking on the environment: A total environmental study paradigm. Science of the Total Environment. 2017, 580, 953-957. [CrossRef] 
37. Carls, E.; Fenn, D.; Chaffey, S. Soil contamination by oil and gas drilling and production operations in Padre Island national seashore, Texas, USA. J. Environ. Manag. 1995, 45, 273-286. [CrossRef]

38. Jose, R.; Heo, J.; Kim, K. The impact of hydraulic fracturing on groundwater quality in the Permian Basin, West Texas, USA. Water. 2020, 12, 796. [CrossRef]

(C) 2020 by the authors. Licensee MDPI, Basel, Switzerland. This article is an open access article distributed under the terms and conditions of the Creative Commons Attribution (CC BY) license (http://creativecommons.org/licenses/by/4.0/). 